\title{
RYNEK WYDAWNICZY LITERATURY DZIECIECEJ I MŁODZIEŻOWEJ W NOWYCH CHINACH
}

W ciagu ostatnich 70 lat branża wydawnicza książek dziecięcych i młodzieżowych w Chińskiej Republice Ludowej przeszła długa droge od niedostatku po dobrobyt, od słabości po potęgę, od izolacji po otwartość. Następujący nieprzerwanie od XXI w. bardzo intensywny rozwój skutkuje tym, że siła chińskich wydawnictw wciąż rośnie ${ }^{1}$.

\section{DOI: $10.4467 / 23538724 G S .20 .050 .13490$}

1 Do opracowania artykułu wykorzystano następujące publikacje: 杨雷（中国）海柔尔·凯 尼恩女士 (英国) 就中国以及全球图书市场情况进行数据解读和趋势分享。中国童书 市场发展趋势上海报告会 (Yang Lei, H. Kenyon, Jiu zhongguo yiji quanqiu tushu shichang qignkuang jinxing shujujiedu he qushi fenxiang ₹hognguo tognshu shichang farhan qushi shanghai baogaobui, 26.03.2019 [Tendencje rozwoju chińskiego rynku literatury dla dzieci i młodzieży, wystapienie nt. interpretacji trendów i danych dot. sytuacji na rynku książki w Chinach i na całym świecie podczas konferencji w Szanghaju]); 王菲菲、王红梅、黄晓燕、敖德就我国童书出版如何夯实原创力量、创 新营销模式、开展版权交流 (Wang Feifei, Wang Hongmei, Huang Xiaoyan, Ao De, Jiu woguo tognshu chuban rube hangshi yuanchuangliliang, chuangxin yingxiaomoshi kaizhan banquan jiaoliu [W jaki sposób chińska branża wydawnicza książek dziecięcych i młodzieżowych zachowuje oryginalność, korzysta z innowacyjnych form marketingu i podchodzi do wymiany praw własności, 24.04.2020]); 海飞: 茁壮成长的新中国童书出版中国新闻出版广电报 (Hai Fei, Zhuozhaung chengzhangde xinz̧ognguo tongshu chuban, Zhongguo xinwen chuban guangdianbao, 19.09.2019 [Prężny rozwój nowych chińskich wydawnictw literatury dla dzieci i młodzieży, „Chińska Gazeta Wiadomości, Wydawców i Nadawców”]); 李昕原创发力，童书市场添活力《人民日报》2019.04.04 (Li Xin, Yuanchuang fali, tongshu chuban tian huoli, Renminribao, 4.04.2019 [Ożywienie rynku książek dla dzieci i młodzieży wraz z przypływem innowacji, „Dziennik Ludowy”]); 安洪民中国近95\% 的出版社都在做童书，挑战与出路要想清楚北京青年报, 14.03.2018 (An Hongmin, Zhognguo jin 95\% de chubanshe douzai zuo tongshu, tiaz̧han yu chulu yao xiang qignchu, Beijing Gignnianbao, 14.03.2018 [Blisko 95\% chińskich wydawnictw publikuje książki dla dzieci i młodzieży - jasno określone wyzwania i ścieżki rozwoju, „Pekińska Gazeta Młodzieżowa”]); 刘昕互联网时代 中 国童书出版将迎来什么国际商报 (Liu Xin, Hulianwang shidai z̧hongguo tongshu chuban jiang yinglai shenme?, Guoji shangbao [Jaka przyszłość czeka chińskie wydawnictwa literatury dla dzieci i młodzieży w erze Internetu?, „Gazeta Międzynarodowego Biznesu”]); 常青、杨文轩、高飞、白 静、邢明旭 投资“下一代”: 中国儿童阅读与内容产业的市场价值第七届中国上海国 际童书展 2019.12.05 (Chang Qing, Yang Wenxuan, Gao Fei, Bai Jing, Xing Mingxu, “Touzi xiayidai": Zhongguo ertong yuedu yu neirong chanyede shichang jianzhbi, Di qijie zhongguo shanghai guoji tognshuzhan, 5.12.2019 [Inwestycja w „przyszłe pokolenia”: Czytelnictwo wśród chińskiej młodzieży i rynkowa wartość branży, wystąpienie podczas VII Międzynarodowych Targów Książki dla Dzie- 
W Chinach wydaje się corocznie ponad 40 tys. nowych książek w łącznym nakładzie 800 mln tomów, co skutkuje tym, że kraj ten jest największą światową potęgą w tej kategorii. Ponad 300 tys. sprzedawanych tytułów daje przychód w wysokości 20 mld juanów (CNY). W Państwie Środka mieszka 367 mln młodych czytelników. Wspomniane czynniki oraz dodatkowo przyjacielskie relacje z wydawnictwami z ponad stu krajów świata sprawiaja, że Chiny są potęgą wydawniczą w dziedzinie książek dziecięcych i młodzieżowych.

Proklamowanie Chińskiej Republiki Ludowej 1 października 1949 r. rozpoczęło zupełnie nowy rozdział w liczącej 5 tys. lat historii cywilizacji tego antycznego kraju. Dwa miesiące po ustanowieniu nowych Chin, czyli w listopadzie 1949 r., władze państwa powołały Generalne Biuro Wydawnicze, co było pierwszym krokiem w stronę rozpoczęcia działania i planowego rozwoju przemysłu wydawniczego w Chinach.

W pierwszych latach istnienia nowego państwa chińskiego centrum wydawnicze Chin było skupione w regionach na południe od rzeki Jangcy, z Szanghajem na czele. W całym kraju działało zaledwie 211 przedsiębiorstw wydawniczych, spośród których 27 stanowiły wydawnictwa państwowe, a 184 znajdowały się w rękach prywatnych. Wydawanych pozycji było niewiele, a ich jakość zła, co w żadnym wypadku nie zaspokajało potrzeb tak ogromnego narodu.

Jeśli chodzi o artykuły dla dzieci i młodzieży, w całym kraju w 1950 r. wydano raptem 466 dziecięcych publikacji, co przekładało się na łączną liczbę ponad 5073000 wydrukowanych egzemplarzy. Aż 70\% wszystkich tytułów i 59\% wszystkich wydrukowanych tomów ukazało się nakładem wydawnictw prywatnych. Ponieważ populacja dzieci i młodzieży w wieku 6-15 lat wynosiła w tamtym czasie

ci w Szanghaju]); 商务君 少儿出版进入新一轮洗牌期，几家欢喜几家愁? 出版商务周报 | 2018年02月27日 (Shangwujun Shaoer chuban jinru xinyilun xipaiqi, jijia buanxi jijiachou?, Chuban shangwu z̧houbao, 27.02.2018 [Wydawnictwa młodzieżowe rozpoczynają nowe rozdanie - kto się cieszy, kto musi się martwić?, „Tygodnik Biznesu Wydawniczego”]); 吴学安童书热, 但别“上瘾”中 国文化传媒网 www.ccdy.cn 14.11.2019 (Wu Xuean, Tognshure, dan bie sabngyin, Zhongguo chuanmei wenhuawang, 14.11.2019 [Literatura dla Dzieci i Młodzieży - popularna, ale nieuzależniająca, Portal Medialny Chińskiej Kultury]; 高翼、徐蕾AR/VR童书出版现状与发展趋势出版广角 2019 年第23期 20-24页 (Gao Yi, Xu Lei, AR/VR Tongshu chuban xianzhuang yu farhan qushi, Chuban guangiiao, 2019, vol. 23, s. 20-24 [Obecny stan i tendencje rozwojowe młodzieżowych wydawnictw AR/VR, „Panorama Wydawnicza”]); 郑欣怡童书出版的发展趋势、问题、建议、感 悟、思考出版广角 2014年第 9期 28-29页 (Zheng Xinyi, Tongshu cbubande faそhban qushi, wenti, jianyi, ganwu, sikao, Chuban guangiiao 2014, vol. 9, s. 28-29 [Wydawcy książek dla dzieci i młodzieży - tendencje rozwojowe, problemy, propozycje, uznanie i rozważania, „Panorama Wydawnicza]); 牟海伟、李师龙 中国童书出版的新局出版广角 2014 年第6期 25-26页 (Mou Haiwei, Li Shilong, Zhongguo tongshu chubande xinju, Chuban guangjiao 2014, vol. 6, s. 25-26 [Nowa runda dla chińskich wydawnictw literatury dziecięco-młodzieżowej, „Panorama Wydawnicza”]); 许春晖 中 国童书出版大趋势探照灯 2012年第3期 7-10页 (Xu Chunhui, Zhongguo tongshu chuban daqushi, Tanzhaodeng 2012, vol. 3, s. 7-10 [Główne trendy na chińskim rynku wydawniczym książek dla dzieci i młodzieży, „Reflektor”]. 
ok. $100 \mathrm{mln}$, średnio na 17 osób w tej grupie wiekowej przypadał zaledwie 1 egzemplarz książki dziecięco-młodzieżowej. Brak wystarczającej liczby książek i innych materiałów drukowanych wpłynął na to, że w tamtym okresie w branży wydawniczej panowała swoista posucha.

Pierwsze wydawnictwo specjalizujące się w literaturze dla dzieci i młodzieży w Chińskiej Republice Ludowej - Wydawnictwo Młodzieżowo-Dziecięce (Shanghai Shaonian Ertong Chubanshe - 上海少年儿童出版社) powołano do życia w Szanghaju w grudniu 1952 r. Natomiast zaledwie 2 lata później, w 1954 r. władze państwowe zakończyły prace nad reforma prywatnego sektora wydawnictw dla dzieci i młodzieży zgodnie z zasadami socjalizmu. Opublikowano wtedy 1260 pozycji książkowych dla dzieci i młodzieży, na co złożyły się nowe wydania i dodruki tytułów już obecnych na rynku. W sumie ukazało się 13690000 egzemplarzy książek, w tym 60\% wydanych tytułów i 80,4\% wydrukowanych egzemplarzy było owocem pracy wydawnictw państwowych i przedsiębiorstw będących pod mieszaną kontrolą państwa i kapitału prywatnego. Wzrósł także stan posiadania książek dziecięco-młodzieżowych, gdyż 1 egzemplarz książki tego typu przypadał już średnio na 5 młodocianych czytelników.

Poważne braki w publikacjach dla dzieci i młodzieży w początkach istnienia nowych Chin stały się troską wszystkich ministerstw państwowych, w których kompetencji leżało zwiększenie dostępności książki drukowanej dla tej grupy czytelników. Sekretariat Komitetu Centralnego Ligii Młodzieży Komunistycznej 15 sierpnia 1955 r. przedstawił Komitetowi Centralnemu Komunistycznej Partii Chin Raport nt. kwestii deficytu materiałów czytelniczych dla współczesnych dzieci i młodzieży. Dokument dotyczył sytuacji w takich regionach, jak Hebei, Jiangsu i Szantung, a ponadto zaproponowano w nim zastosowanie środków „zdecydowanego wzbogacenia twórczości literatury dla dzieci i młodzieży” oraz „zwiększenia mocy wydawniczych literatury dziecięco-młodzieżowej”.

Komitet Centralny KPCh 27 sierpnia 1955 r. zaaprobował raport Ligii Młodzieży Komunistycznej i zobowiązał odpowiednie organy w całym kraju do aktywnej i usystematyzowanej pracy nad polepszaniem warunków tworzenia, tłumaczenia, wydawania i dystrybucji książek dla dzieci i młodzieży. Dnia 5 października 1955 r., po ustanowieniu struktury organizacyjnej Rady Państwa ChRL, odpowiedzialne za branżę wydawniczą kierownictwo Ministerstwa Kultury przedstawiło przed Komitetem Centralnym KPCh raport, w którym zaproponowało cztery środki mające na celu zwiększenie możliwości wydawniczych i dystrybucyjnych książek dla dzieci i młodzieży.

Po pierwsze, należało zdecydowanie zwiększyć liczbę wydawanych tytułów i drukowanych egzemplarzy książek dziecięco-młodzieżowych. Po upływie planowych 2 lat liczba wydawanych pozycji miała wzrastać każdego roku o 25\%, a liczba drukowanych tomów o 20\%. Wzrosnać miało także wynagrodzenie dla autorów z 5-15 CNY za 1000 znaków do 10-30 CNY (ówcześnie najwyższe wynagrodzenia 
pisarskie wynosiły zwykle $25 \mathrm{CNY}$ ). Wynagrodzenie autorów miało być też uzależnione od liczby wydrukowanych egzemplarzy.

Po drugie, proponowano zwiększenie mocy wydawniczej literatury dla dzieci i młodzieży. Równocześnie z powołaniem Wydawnictwa Dziecięco-Młodzieżowego na szczeblu centralnym należało również zwiększyć działalność w zakresie publikacji literatury tego typu przez już działające na szczeblu centralnym wydawnictwa, takie jak: Ludowe Wydawnictwo Sztuk Pięknych, Ludowe Wydawnictwo Edukacyjne, Wydawnictwo Czytelnictwa Popularnego czy Wydawnictwo Muzyczne oraz szanghajskie Nowe Wydawnictwo Sztuk Pięknych. Wydawnictwa działające w poszczególnych regionach także miały zwracać uwagę na twórczość lokalnych pisarzy przeznaczoną dla dzieci i młodzieży, stopniowo organizować biura redakcyjne lub grupy redaktorów literatury dziecięco-młodzieżowej.

Po trzecie, zalecano poprawę jakości papieru i jakości druku książek dla dzieci, a także obniżenie ich ustalonej ceny.

Po czwarte, zwrócono uwage na konieczność intensyfikacji prac na publikacją literatury dziecięco-młodzieżowej.

Dnia 1 czerwca 1956 r. z inicjatywy Komitetu Centralnego Ligi Młodzieży Komunistycznej założono Chińskie Wydawnictwo Młodzieżowo-Dziecięce w Pekinie (Zhongguo Shaonian Ertong Chubanshe - 中国少年儿童出版社). Był to drugi zakład wydawniczy tego typu w Chińskiej Republice Ludowej. Powstała wtedy nowa struktura rynku wydawnictw dziecięcych i młodzieżowych, którą obrazują odnoszące się do lokalizacji i nazewnictwa obu zakładów powiedzenia: „dzieci Południa mają książki szanghajskie, a dzieci Północy chińskie”, a także odnoszące się do zawartości publikacji: „materiałów popularnonaukowych szukaj w szanghajskim, a myśli edukacyjnej w chińskim".

Partyjne kadry kierownicze Ministerstwa Kultury i Sekretariat Centralny Ligi Młodzieży Komunistycznej 26 lutego 1960 r. wspólnie przekazały KC KPCh Raport nt. dalszych postępów w poprawie czytelnictwa dziecięco-młodzieżowego, który odnosił się do kwestii związanych z różnorodnością, jakością bądź rozwojem czytelnictwa w danej grupie wiekowej w latach 1957-1959 w całym kraju. W ciągu tych 3 lat wydano 5937 pozycji dla dzieci i młodzieży, co przełożyło się na $189 \mathrm{mln}$ wydrukowanych egzemplarzy. Choć liczba drukowanych tytułów i tomów wyraźnie wzrosła, jednakże książek o charakterze filozoficznym bądź artystycznym wciąż było niewiele, odnotowano też niedobory książek wzbogacających wiedzę, a zakres tematyczny literatury był wąski. Brakowało zarówno pozycji dla dzieci najmłodszych, które nie rozpoczęły jeszcze nauki, jak i książek obrazkowych. Podobnie miała się sprawa z książkami dla dzieci i młodzieży wiejskiej. Jakość wydruku była niska, a ilustracje nieczytelne. Komitet Centralny KPCh 5 marca 1960 r. zaaprobował raport i rozesłał go do oddziałów regionalnych w całym kraju. W latach 1960-1965 w całych Chinach wydano 4967 pozycji dla dzieci i młodzieży o łącznej liczbie 273 mln egzemplarzy. Znacząco wzrosła także jakość wydruku. 
Od 1 października 1949 do grudnia 1965 r., a więc w ciągu 16 lat przypadających na istnienie nowego państwa chińskiego Chiny mogły poszczycić się posiadaniem własnych wydawnictw książek dziecięco-młodzieżowych. W czasie tych 16 lat w całym kraju wydano łącznie 19671 książek dla dzieci i młodzieży, spośród których 10723 stanowiły wydania zupełnie nowe. Wydrukowano $671 \mathrm{mln}$ egzemplarzy ksiażek, co przełożyło się na $1 \mathrm{mld}$ i 480 mln kartek. W ciągu tych lat w całych Chinach pojawiły się również liczne grupy czytelników tego typu książek, którzy mogli cieszyć się wybitnymi dziełami literackimi autorstwa świetnych, wyspecjalizowanych w literaturze dziecięco-młodzieżowej pisarzy.

W lipcu 1960 r. Szanghajskie Wydawnictwo Młodzieżowo-Dziecięce rozpoczęło wydawanie chińskiej popularnonaukowej książki dla dzieci i młodzieży pt. 100 tysięy dlaczego. Wykorzystując najczęściej zadawane przez najmłodszych pytania, zebrano 1484 zagadnień - tematów do opracowania. Tylko pomiędzy lipcem 1960 r. a kwietniem 1964 r. rozeszło się łącznie ponad 5 mln 800 tys. egzemplarzy tej książki. Aż 19 prowincji postanowiło wydać tę pozycję w innych wersjach językowych, np. w językach mongolskim, ujgurskim, kazachskim czy koreańskim, a także w wersji brajlowskiej dla osób niewidomych. Prawa do wydania książki zostały także sprzedane wydawnictwom z Wietnamu, Indonezji i innych krajów.

W 1966 r. rozpoczęła się w Chinach rewolucja kulturalna, która spowodowała ogromne zniszczenia w jeszcze nie w pełni okrzepłej branży wydawniczej książek dla dzieci i młodzieży. Cały dziecięco-młodzieżowy przemysł wydawniczy zamarł, powodując przy tym bardzo poważne niedobory książek. Chińskie Wydawnictwo Młodzieżowe i Chińskie Wydawnictwo Młodzieżowo-Dziecięce wznowiły działalność wydawniczą dopiero w październiku 1975 r. W ślad za nimi stopniowo budziła się do życia branża wydawnicza dla młodych czytelników w całych Chinach.

W ramach III sesji plenarnej XI Kongresu Narodowego Komunistycznej Partii Chin w 1978 r. sformułowano nową polityczną linię Partii, która za główny cel obrała sobie budowę silnej gospodarki. Chiny wkroczyły w okres nowatorskich reform i polityki otwarcia. Przywrócone do działania po zakończeniu rewolucji kulturalnej Narodowe Biuro Wydawnicze na początku maja 1978 r. zaprosiło wydawnictwa z Pekinu, Szanghaju, Kantonu i innych miast do udziału w roboczej konferencji mającej na celu zebranie i omówienie problemów związanych z wydawaniem książek dla dzieci i młodzieży w całym kraju oraz znalezienie sposobów ich rozwiązania. Następnie 28 maja 1978 r. upoważniło Ludowe Wydawnictwo Literackie do zorganizowania w stolicy konferencji twórców literatury dziecięco-młodzieżowej. Podczas spotkania wezwano pisarzy do zerwania kajdan ograniczających ich ducha twórczego, wzięcia piór do rąk i pisania dla dzieci, by ocalić je od lekturowej posuchy.

Narodowe Biuro Wydawnicze w dniach 11-19 października 1978 r. zorganizowało w Lushan, w prowincji Jiangxi Ogólnokrajową konferencję roboczą ds. pracy wydawnictw książek dla dzieci i młodzieży. Spotkanie w Lushan było pierwszym w historii branży wydawniczej w Chinach pokazem wolności myśli. Dążono do 
przywrócenia porządku zburzonego przez niepokoje rewolucji kulturalnej. Szukano prawdy, odważnie wkraczając na dotychczas zakazane rejony. Konferencja ta stała się symbolem nadejścia wiosny w dziecięco-młodzieżowym przemyśle wydawniczym. W czasie spotkania sformułowano główne punkty trzyletniego planu wydawniczego książek dla dzieci i młodzieży na lata 1978-1980, a także ustalono motywujący do działania ambitny cel wydania tysiąca tytułów dla dzieci i młodzieży przed Dniem Dziecka 1 czerwca 1979 r. oraz opublikowania 29 serii książek w ciagu 3 lat. Cel ten został zrealizowany w pełni dzięki wytężonej pracy pracowników wydawnictw całego kraju i pozytywnym nastrojom okresu „reform i otwarcia”.

W sformułowanym i wprowadzonym w życie przez Generalne Biuro ds. Prasy i Publikacji IX Planie Pięcioletnim, który dotyczył głównych celów krajowych wydawnictw książkowych, doceniono wage wydawnictw dla dzieci i młodzieży oraz pisano o „treści, na którą należy zwrócić szczególną uwage” w dziedzinie wydawnictw dziecięco-młodzieżowych. Ostatecznie spośród 1200 elementów państwowego IX Planu, nazywanego często „planem 1200 projektów”, 85 odnosiło się do materiałów czytelniczych dla dzieci i młodzieży, co stanowiło 7\% całego planu. W X i XI Planie odsetek zagadnień odnoszących się do literatury dla dzieci i młodzieży nieustannie rósł.

Dnia 24 czerwca 1996 r. Wydział Propagandy KPCh i Generalne Biuro ds. Prasy i Publikacji rozpoczęły realizację projektu publikacji chińskich komiksów i animacji przeznaczonych dla dzieci i młodzieży, który miał na celu intensywny rozwój tego typu wybitnych dzieł o chińskiej charakterystyce. Projekt ten nazywano „Projektem 5, 15 i 5", gdyż zakładał utworzenie 5 baz wydawniczych we wschodniej, północnej, południowej, północno-wschodniej i zachodniej części Chin, wydanie 15 kluczowych, szeroko zakrojonych serii książek komiksowych, jak również utworzenie 5 powiązanych magazynów, np. „Chińskie kreskówki” (z̧ognguo katong《中国卡通》). Było to duży krok w chińskiej branży książek komiksowych i animacji, który położył solidne podstawy pod rozwój chińskiego komiksu i chińskich animacji na poczatku XXI w.

Przed wprowadzeniem polityki „,reform i otwarcia” podstawową strukturę chińskiej branży wydawniczej specjalizującej się w pozycjach dla dzieci i młodzieży można oddać przywołanym już sformułowaniem: „dzieci Południa mają książki szanghajskie, a dzieci Północy chińskie", co wyraźnie wskazuje na dwa główne ośrodki wydawnicze. Zatrudniały one zarówno ponad 200 redaktorów skupionych w zespołach poświęconych literaturze dla dzieci i młodzieży, jak i liczące ponad 200 osób zespoły twórców literackich, które potrafily wypuścić na rynek 752 książki. W pozostałej części ówczesna dziecięco-młodzieżowa branża wydawnicza w Chinach składała się całkowicie z małych wydawnictw, które nie były w stanie zaspokoić ogromnego popytu.

Niezwykle szybki rozwój nie ominął również zespołów redakcyjnych, wydawniczych i twórczych działających na polu literatury dla dzieci i młodzieży. Do 2008 r. 
w całych Chinach działały 34 wydawnictwa specjalizujące się w wydawaniu książek dziecięco-młodzieżowych, jak również ponad 260 wydawnictw gazet i magazynów dla tej grupy wiekowej, skupiających ponad 6 tys. wyspecjalizowanych pracowników i ponad 5 tys. pisarzy oraz ilustratorów. Równocześnie spośród działających w całych Chinach ponad 570 wydawnictw aż 521 posiadało oddzielne wydziały redakcyjne poświęcone materiałom czytelniczym dla dzieci i młodzieży. Niektóre $\mathrm{z}$ wydawnictw uniwersyteckich także założyły oddziały specjalizujące się w literaturze dziecięco-młodzieżowej, jak np. Wydawnictwo Nauki i Badań Języków Obcych (Wiayu Jiaoxue Yu Yanjiu Chubanshe - 外语教学与研究出版社) czy Wydawnictwo Pekińskiego Uniwersytetu Pedagogicznego (Dongbei Shifandaxue Chubanshe - 东北师范大学出版社).

Chińskie Wydawnictwo Młodzieżowo-Dziecięce i Chińska Gazeta Młodzieżowa w maju 2000 r. nawiązały ścisłą współpracę, która zaowocowała powstaniem pierwszej w Chinach grupy medialnej kierującej swoją ofertę do dzieci - Chińskiej Młodzieżowo-Dziecięcej Spółdzielni Informacyjno-Wydawniczej (Zhongguo Shaonian Ertong Xinwen Chubanzongshe - 中国少年儿童新闻出版总社). Ponad 30 lokalnych wydawnictw i redakcji również kolejno połączyło się w grupy wydawnicze, krocząc drogą rozwoju w ramach całej grupy. Agencje wydawnicze specjalizujące się w literaturze dziecięcej i młodzieżowej w całym kraju wprowadziły w życie plan restrukturyzacji branży, odkrywając i przecierając nowy szlak rozwoju tego przemysłu.

Żywiołowy rozwój wydawnictw dla dzieci i młodzieży przyczynił się także do postępów w dziedzinie zawiązywania się stowarzyszeń w branży. W 1986 r., przy dużym wsparciu ze strony Generalnego Biura ds. Prasy i Publikacji Chiny wstąpiły do Międzynarodowej Izby ds. Książek dla Młodych (IBBY), nazywanej małą Organizacją Narodów Zjednoczonych w kręgach wydawnictw dla dzieci i młodzieży. Założono także Chińską Sekcję Międzynarodowej Izby ds. Książek dla Młodych (CBBY). Było to otwarcie wrót do komunikacji chińskich wydawnictw dziecięco-młodzieżowych ze światem zewnętrznym. Branża wydawnicza Chin, państwa izolowanego na arenie międzynarodowej do czasu „reform i otwarcia”, rozwinęła się na tyle, by nawiązać przyjacielskie relacje z ponad 100 krajami i ponad 600 regionalnymi oddziałami wydawnictw.

W 1994 r., przy wsparciu Stowarzyszenia Pracowników Chińskich Wydawnictw, powołano Komisję Roboczą ds. Pracy Chińskich Wydawnictw Młodzieżowo-Dziecięcych. Każdego roku organizowane jest spotkanie przewodniczących Komisji i prezesów wydawnictw dla dzieci i młodzieży z całych Chin. Obrady skupiają się na badaniu i dyskusji na temat aktualnego stanu chińskich wydawnictw dziecięco-młodzieżowych oraz kierunków rozwoju branży. Corocznie organizowane są także Ogólnokrajowe Targi Książki dla Dzieci i Młodzieży, podczas których wydawnictwa specjalizujące się w tego typu literaturze mogą zaprezentować rezultaty swojej pracy, podzielić się wiadomościami z branży, a także wejść na rynek wydawniczy. 
Każdego roku wybiera się ponadto „10 Największych Wydarzeń Chińskiej Branży Wydawniczej dla Dzieci i Młodzieży", co potwierdza prawdziwe postępy chińskich wydawnictw od czasu wprowadzenia polityki „reform i otwarcia”. 1 lipca 1997 r. Komisja wydała kompleksowe opracowanie pt. „Chińskie wydawnictwa dla dzieci i młodzieży”, w którym zawarła wyczerpującą interpretację polityki prowadzonej przez wydawnictwa.

W ciagu 40 lat od wprowadzenia polityki „reform i otwarcia” rynek wydawniczy książek dla dzieci i młodzieży przeszedł drogę od niedoborów po dostatek, od ascetyzmu po elegancję. Żaden inny typ książek nie odnotował tak szybkiego wzrostu ani pod względem liczby i różnorodności wydawanych pozycji, ani pod względem doskonalenia jakości. Można zaobserwować ciagły wzrost liczby publikacji (zob. tab. 1). Książki dla dzieci i młodzieży są nie tylko najpiękniejsza, najbardziej przykuwającą uwagę częścią ekspozycji księgarń krajowych, ale też za granicą stanowią najmocniej wyróżniającą się chińskimi cechami charakterystycznymi i stylem część asortymentu księgarń.

Tab. 1. Łączna liczba książek dla dzieci i młodzieży wydanych w Chinach w kolejnych latach

\begin{tabular}{|c|c|c|c|c|c|c|c|c|}
\hline Rok & 1977 & 1979 & 1980 & 1989 & 1991 & 1992 & 1994 & 2000 \\
\hline $\begin{array}{c}\text { Liczba } \\
\text { książek }\end{array}$ & 752 & 1100 & 2400 & 3598 & 4000 & 4605 & 6000 & 7004 \\
\hline
\end{tabular}

Źródło: Opracowanie własne.

Z informacji publikowanych przez Generalne Biuro ds. Prasy i Publikacji wynika, że w 2006 r. w całych Chinach wydano 9376 tytułów dla dzieci i młodzieży (spośród których 5360 zadebiutowało na rynku), co przełożyło się na $199 \mathrm{mln}$ 750 tys. egzemplarzy i 972 mln 961 tys. kartek oferowanych za łączną kwotę o wartości $1795010000 \mathrm{CNY}$. W całym kraju w sprzedaży znajdowało się 98 gazet i magazynów dla dzieci i młodzieży, których uśredniony nakład wynosił $11 \mathrm{mln}$ 160 tys. egzemplarzy, a nakład każdego z tytułów w jednostce czasu oscylował wokół 113900 egzemplarzy. Łącznie wydrukowano $221 \mathrm{mln} 80$ tys. egzemplarzy i 605 mln 644 kartki. Opublikowano też 1834 pozycje w dziedzinie taśm audio dla dzieci i młodzieży, co przełożyło się na 11614400 pudełek na rynku. Wydano także 799 pozycji jako płyty CD dla dzieci i młodzieży, łącznie 4646300 płyt oraz 2 pozycje w wersji DVD-A, które przełożyły się na 5500 płyt. Na rynku pojawiło się również 6 pozycji w formie kaset wideo - 10200 pudełek, a także 2231 tytułów na płytach VCD w liczbie 24648200 egzemplarzy. Dzieci i młodzież mogły cieszyć się również wydaniem 279 pozycji w formie płyt DVD-V w łącznej liczbie 6318100 egzemplarzy. W całych Chinach sprzedano $351 \mathrm{mln}$ książek dla dzieci i młodzieży za łączną sumę $3 \mathrm{mld} 410 \mathrm{mln}$ CNY. Materiały czytelnicze dla dzieci i młodzieży zostały wyeksportowane z Chin w liczbie 67750 tytułów, co przełożyło 
się na 507400 tomów o wartości 1225100 USD. Importowane materiały czytelnicze dla dzieci i młodzieży osiagnęły pułap 19646 tytułów w liczbie 325200 tomów o łącznej wartości 2414300 USD.

W ciagu 40 lat od momentu wprowadzenia polityki reform i otwarcia pojawiła się w Chinach grupa świetnych agencji wydawniczych i wydawnictw specjalizujących się w literaturze dla dzieci i młodzieży, a także równie wybitnych pisarzy i ilustratorów, co przełożyło się na liczne fenomenalne książki dziecięco-młodzieżowe. Do najlepszych są zaliczane Chińskie Wydawnictwo Młodzieżowo-Dziecięce, Wydawnictwo Młodzieżowo-Dziecięce, Wydawnictwo Młodzieżowo-Dziecięce w Zhejiang oraz Wydawnictwo Jieli. Ponad 10 wydawców literatury dla dzieci i młodzieży zostało uhonorowanych Nagrodą Wydawniczą im. Zou Taofen, ponad 20 pracowników wydawnictw dla dzieci i młodzieży może poszczycić się tytułem wybitnego pracownika zakładu wydawniczego, a ponad 30 prezesów wydawnictw literatury dziecięco-młodzieżowej zostało awansowanych na ważniejsze stanowiska. Kilkaset książek dla dzieci i młodzieży uzyskało jedną z trzech wielkich chińskich nagród książkowych, a blisko tysiąc książek dziecięco-młodzieżowych zdobyło wielorakie nagrody dla wybitnych dzieł literatury dziecięcej.

W ciagu ostatnich 40 lat w zakresie chińskich popularnonaukowych materiałów czytelniczych dla dzieci i młodzieży dokonał się znaczący postęp. Odsetek tego typu literatury w ramach ogółu pozycji dziecięco-młodzieżowych wydawanych w Chinach nieustannie rośnie. W 1996 r. kształtował się na poziomie 11\% całości, podczas gdy w 2000 r. było to $21 \%$, a w 2006 r. 24\%. Nazywana encyklopedycznym cudem Chin Chinska encyklopedia dla dzieci i młodzieży, wydana przez Wydawnictwo Edukacyjne w Zhejiang, w ciagu 7 lat była wznawiana ponad dwudziestokrotnie. Przez 4 kolejne lata znajdowała się wśród 10 najlepiej sprzedających się książek w Chinach. Wydano ją łącznie w nakładzie ponad 1700000 egzemplarzy, których wartość przekroczyła $100 \mathrm{mln}$ CNY.

Trwający od 40 lat proces otwierania się chińskich wydawnictw dziecięco-młodzieżowych na rynki zagraniczne można podzielić na trzy etapy.

Pierwszy, wstępny okres trwał od 1978 do 1990 r. Był to czas ostrożnego eksperymentowania. W 1979 r. Chińskie Wydawnictwo Młodzieżowo-Dziecięce i Wydawnictwo Młodzieżowo-Dziecięce wydały nowe tłumaczenia wybitnych zagranicznych utworów literatury dziecięcej i młodzieżowej, które były zakazane w czasach rewolucji kulturalnej. Podejmowano przy tym próby nawiązania współpracy z wydawnictwami zagranicznymi w zakresie uzyskania licencji.

Drugi etap rozwoju rozpoczął się od wprowadzenia w Chińskiej Republice Ludowej praw autorskich w 1991 r. i trwał do końca XX w. W 1992 r. Chiny stały się członkiem Światowej Organizacji Własności Intelektualnej i ratyfikowały Powszechną konwencję o prawie autorskim, zrewidowaną w Paryżu dnia 24 lipca 1971 r. Chińskie wydawnictwa dla dzieci i młodzieży zostały poddane procesowi jeszcze bardziej otwartej i szeroko zakrojonej internacjonalizacji. Jeśli wziąć pod uwage 
ogół chińskich wydawnictw, można odnotować, że w 1990 r. prawa wydawnicze nie obejmowały nawet tysiąca pozycji książkowych, natomiast do roku 2000 liczba ta przekroczyła 7 tys. tytułów. W konsekwencji książki dla dzieci i młodzieży zwiększyły swój udział odpowiednio od 100 książek w 1990 r. do ponad 800 w 2000 r. W tym okresie chińskie wydawnictwa dziecięco-młodzieżowe zdecydowanie wkroczyły na arenę międzynarodowa, wielokrotnie biorąc udział w Targach Książki we Frankfurcie, Międzynarodowych Targach Książki dla Dzieci w Bolonii i innych wydarzeniach międzynarodowych. W Pekinie ponadto dwukrotnie zorganizowano Międzynarodowe Targi Książki dla Dzieci.

Trzeci etap zaczął się od XXI w., kiedy to Chiny stały się członkiem Światowej Organizacji Handlu i nastapił okres rozkwitu i prosperity, do czego się przyczynił rozwój sieci międzynarodowych połączeń kolejowych. Chińskie wydawnictwa dla dzieci i młodzieży bardzo szybko dołączyły do grona podobnych sobie wydawnictw na świecie. Międzynarodowa społeczność wydawców również z bardzo dużym szacunkiem przygląda się Chinom jako ogromnemu rynkowi dla książek dziecięcych, na którym wydawanych jest wiele doskonałych zagranicznych pozycji i bestsellerowych książek dla dzieci i młodzieży. Wybitne chińskie utwory również zaczęły przekraczać granice kraju, a niektóre z istotnych międzynarodowych konferencji i wydarzeń zaczęto organizować w Chinach.

Chiński rynek książek dla dzieci i młodzieży może poszczycić się największą na świecie liczbą posiadanych zagranicznych praw autorskich i wydawniczych, która każdego roku zwiększa się o 6 tys. do 8 tys. tytułów. Przykładem sukcesu książki importowanej może być bestsellerowa seria o Harrym Potterze autorstwa brytyjskiej pisarki Joanne K. Rowling, która została w Chinach wydana przez Ludowe Wydawnictwo Literackie i przez 27 kolejnych miesięcy utrzymywała się na szczycie list najlepiej sprzedających się książek. Chińskie Wydawnictwo Młodzieżowo-Literackie wydało natomiast belgijskie Praygody Tintina i szwedzkie Drieła zebrane Astrid Lindgren, Wydawnictwo Młodzieżowo-Dziecięce w Zhejiang wprowadziło na rynek serię książek Sprawa dla ciebie i Drużyny Tygrysów, Wydawnictwo Jieli opublikowało serie Gesia skórka oraz Smerfy, Wydawnictwo Młodzieżowo-Dziecięce w Anhui wydało Zbiór Nagrody im. Hansa Christiana Andersena, Wydawnictwo Nadzieja opublikowało serię książek Snoopy, a Wydawnictwo XXI Wieku wprowadziło na rynek Wielka literature fantastycznq. W związku z 200. rocznica narodzin Hansa Christiana Andersena obchodzoną w 2005 r. podliczono, że do tego roku opublikowano w Chinach ponad 200 książek z jego baśniami, które rozeszły się w ponad $10 \mathrm{mln}$ egzemplarzy. Wydanych zostało bardzo wiele pochodzących z różnych krajów wybitnych utworów dla dzieci i młodzieży, co sprawiło, że na początku XXI w. przed chińskim rynkiem książki zarysowały się świetlane perspektywy. Dzięki poszerzeniu oferty książek mali chińscy czytelnicy mieli dostęp do tych samych dzieł, co ich zagraniczni koledzy. 
Niezwykle szybki rozwój chińskich wydawnictw dla dzieci i młodzieży, a także pozycja tego kraju jako czytelniczego mocarstwa w tej kategorii sprawily, że świat zaczął zwracać na Chiny coraz większą uwagę. Począwszy od 1996 r., kolejni przewodniczący Międzynarodowej Izby ds. Książek dla Młodych (IBBY) wielokrotnie wystosowywali zapytania do chińskiego oddziału o możliwość zorganizowania konferencji IBBY w kraju o największej populacji i największej grupie młodzieżowych czytelników. Po 10 latach przygotowań, 30. Światowa Konferencja Międzynarodowej Izby ds. Książek dla Młodych odbyła się w dniach 20-23 września 2006 r. w Makao. Wzięło w niej udział ponad 500 przedstawicieli z 54 krajów. Równolegle z konferencją organizowano 10 wystaw, w tym Wystawę Nagrody im. Hansa Christiana Andersena i Wystawę Listy Honorowej IBBY. W 2017 r. na przewodniczącego IBBY wybrano obywatela Chin, Zhanga Mingzhou.

$\mathrm{Na}$ początku nowego tysiąclecia struktura branży wydawniczej książek dla dzieci i młodzieży była nazywana w kręgach przemysłowych „strukturą całego kraju”, gdyż spośród ponad 580 działających wydawnictw więcej niż 550 zajmowało się wydawaniem książek młodzieżowych - prawie każde wydawnictwo miało w swojej ofercie tytuły dla dzieci i młodzieży. Struktura ta zmieniła się jednak wraz z postępującym wzrostem jakości książek dla dzieci.

W 2013 r. w centralnych Chinach powstała Młodzieżowo-Dziecięca Grupa Wydawnicza Jangcy. Była to organizacja wydawnicza powstała w wyniku połączenia się Wydawnictwa Młodzieżowo-Dziecięcego w Hubei i Przedsiębiorstwa Wydawniczego Delfin (Haitung Chubanshe - 海豚出版社). Niedługo potem, 1 grudnia 2014 r., w efekcie wewnętrznego podziału, powstała Grupa Wydawnicza XXI Wieku. Natomiast 28 listopada 2015 r. doszło do fuzji Przedsiębiorstwa Kulturalnej Podróży Epoki w Anhui i Wydawnictwa Młodzieżowo-Dziecięcego w Anhui, nazywanego czarnym koniem wydawnictw dla dzieci i młodzieży. W efekcie tych połączeń powstało przedsiębiorstwo Epoka Rozwoju Kultury dla Dzieci i Młodzieży S.A. Wcześniej, 23 maja 2000 r., współpraca Chińskiego Wydawnictwa Młodzieżowo-Dziecięcego i Chińskiej Gazety Młodzieżowej zacieśniła się, co doprowadziło do powstania Chińskiej Młodzieżowo-Dziecięcej Spółdzielni Informacyjno-Wydawniczej. W rzeczywistości była to zlokalizowana w Pekinie i wychodząca poza tradycyjne media grupa wydawnicza dla dzieci i młodzieży, która działała na skalę krajowa.

Roczna wartość produkcji każdej z wymienionych wyżej czterech grup przekraczała 1 mld CNY, łącznie dochodząc nawet do 5 mld CNY, co stanowiło $25 \%$ całej wartości odnotowanej w branży. Poza tym nasiliły się tendencje specjalizacyjne w przemyśle wydawniczym dla dzieci i młodzieży. Przykładowo rozwój sześciu wydawnictw ze Wschodu sprawił, że horyzont działalności wydawnictw specjalistycznych poszerzył się, a ich standardy nieustannie rosły. W kwietniu $2015 \mathrm{r}$. Wydawnictwo Młodzieżowo-Dziecięce w Zhejiang założyło filię odpowiedzialną za literaturę. Położone w bardzo dogodnym punkcie nad Cieśniną Tajwańską Wydawnictwo Młodzieżowo-Dziecięce w Fujian wykorzystało swoją lokalizację, wpro- 
wadzając na rynek serię książek Biblioteczka Tajwańskiej Literatury Dziecięcej. Doprowadziło to do powstania nowej, wysoce wyspecjalizowanej i wysoce skoncentrowanej struktury wydawniczej. Równoległe pojawiło się bardzo wiele wydawnictw działających $w$ innych dziedzinach niż literatura dziecięco-młodzieżowa, jak również prywatnych młodzieżowo-dziecięcych inicjatyw wydawniczych zasilanych kapitałem zagranicznym. Przykładem może być powstanie takich wydawnictw, jak Nowe Klasyki (Xinjigndian - 新经典), CITIC (Xiaozhongxin - 小中信), Dziecięca Radość (Tongqu - 童趣), Mniszek (Pugongying - 蒲公英), Guomai (果麦) i Magiczny Słoń (Mofaxiang - 魔法象), Pupulan (蒲蒲兰) czy Wielka Niedźwiedzica (Beidou - 北斗).

Wraz z nadejściem ery Internetu tradycyjne wydawnictwo książek dla dzieci wkroczyło w czas rozwoju mieszanego modelu konkurencyjnego „wydawnictwo dziecięce plus". Przykładem może być Młodzieżowo-Dziecięce Grupa Wydawnicza Jangcy, która opracowała model „wydawnictwo dziecięce plus edukacja przedszkolna”. Grupa ta stworzyła „Warsztat nauki Jangcy” oraz pierwszą w historii chińskiej edukacji przedszkolnej platformę w chmurze, łącząc ze sobą sferę on- i offline. Skonsolidowała również w jedno ciało systemy zarządzania przedszkolami, treścią i przebiegiem zajęć, aktywnościami domowymi, środowiskiem nauki poprzez zabawę, zakupami dla domu oraz elektroniczną platformę zakupów B2C. Zwracała uwagę na potrzebę powołania komitetu badawczego edukacji przedszkolnej w Hubei, działającego pod nazwa: Specjalistyczny Komitet Programu i Edukacji Przedszkolnej. Jego zadaniem jest $\mathrm{z}$ jednej strony badanie cieszącej się dużą popularnością w przedszkolach serii „Działać i Uczyć się” (Bianzuo bianxue - 边做边学), która obejmuje materiały edukacyjne służące do nauki poprzez zabawę, z drugiej zaś rozwój tej serii.

Kolejnym przykładem może być Wydawnictwo Nauczania i Badania Języków Obcych, którego oddział dziecięco-młodzieżowy zdecydował się skorzystać z dobrej koniunktury na rynku nauczania języków obcych i przygotował „zestawy nauczania języków obcych” w myśl strategii „wydawnictwa dziecięce plus przedszkola". Przygotowano dwa zestawy - jeden z książkami obrazkowymi, drugi z materiałami do nauki języka angielskiego dla dzieci. Przedszkola korzystające z oferty były informowane, które z książek obrazkowych i materiałów do nauki języka angielskiego nadają się dla dzieci jednorocznych, które dla dwulatków i tak aż do wieku poprzedzającego rozpoczęcie edukacji w szkole podstawowej. Wydawnictwo przeszkoliło specjalistycznie grupę nauczycieli, z których każdy był przynajmniej studentem studiów magisterskich i posługiwał się językiem angielskim na dobrym poziomie, a także umiał dobrze nauczać z wykorzystaniem książek obrazkowych. Przeszkoleni nauczyciele podróżują od prowincji do prowincji i pomagają się rozwijać przedszkolom. Zestawy książkowe są oferowane nieodpłatnie, gdyż model biznesowy zakłada uzyskanie przychodów z nauczania, a nie ze sprzedaży książek. 
Innym przykładem może być Pekińskie Centrum Wydawnicze Wydawnictwa Uniwersyteckiego w Jiangxi, które przyjęło model „wydawnictwo dziecięce plus zabawki dla dzieci plus ręcznie robione produkty inteligentnego rozwoju”, nazywany też „wydawnictwo dziecięce plus artykuły nieksiążkowe”. Wydawnictwo to sprzedało już prawa wydawnicze do 49 różnych produktów zagranicznym firmom z Wietnamu i innych krajów Azji Południowo-Wschodniej. Jednym z tych artykułów jest bardzo nowatorski i kreatywny zestaw „włóczek do pocierania” (maomaoshua bianzhi - 毛毛刷编织), z których można tworzyć dowolne wymyślne kształty przy użyciu tylko ruchu rąk. Są one wręcz uwielbiane przez najmłodszych. Bawiąc, uczą i naturalnie rozwijaja przy tym umysł dziecka.

Wraz z tendencją do łączenia się w grupy w obrębie chińskiej branży wydawniczej oraz nadejściem wzrostowej fali na rynkach narodził się także model „wydawnictwo dziecięce plus kapitał”. Obecnie wiele chińskich wydawnictw książek dla dzieci i młodzieży opiera się na grupach kapitałowych i spółkach giełdowych, które zapewniaja znaczny przepływ kapitału. Wydawnictwa te dzięki operacjom kapitałowym wykorzystywały posiadane aktywa wydawnicze, aby odpowiednio dostosować liczbę wydawanych pozycji i działania w dziedzinie pozyskania nowych praw.

Proces internacjonalizacji chińskich wydawnictw dziecięco-młodzieżowych przebiega bardzo szybko i nie opiera się już na prostym modelu handlu prawami wydawniczymi na zasadzie ,ja kupuję od ciebie, ty kupujesz ode mnie”. Ogólnie rzecz ujmując, można wyodrębnić pięć różnych modeli.

Pierwszy z nich to współpraca prowadząca do wydania książki. Przykładowo, Wydawnictwo XXI Wieku (Ershiyi Shiji Chubanshe - 二十一世纪出版社) zaprosiło polskiego rysownika Michała Grejnieca do Nanchang. Po 6 miesiącach wspólnych wysiłków udało się wydać całą serię książek obrazkowych, m.in. Bardžo śpiacego weża (Haokun haokunde she - 《好困好困的蛇》). Wydawnictwo to nawiązało podobną współpracę z japońskim rysownikiem Susumu Kinoshita, która zaowocowała powstaniem książki obrazkowej pt. Opowieść o pandzie (Xiongmaode gushi - 《熊猫 的故事》). Zaproszenie do współpracy brazylijskiego laureata Nagrody im. Hansa Christiana Andersena w dziedzinie ilustracji Rogera Mello i chińskiego pisarza Cao Wenxuan doprowadziło do wydania Pióra (Yumao - 《羽毛》), Cytrynowego motyla (Ningmengdie - 《柠檬蝶》) i innych książek obrazkowych. Połączenie sił przez brytyjską ilustratorkę chińskiego pochodzenia Yu Rong (郁蓉) i pisarkę Qin Wenjun (秦文君) zaowocowało powstaniem Jestem Hua Mulan (Wo shi huamulan 《我是花 木兰》). Współpraca hiszpańskiego rysownika Javiera Zabali i chińskiego pisarza Jin Bo zakończyła się publikacją Chce lataí (Wo yao fei 《我要飞》), a kooperacja argentyńskiej ilustratorki Yael Frankel i pisarza Zhang Zhilu (张之路) zaowocowała wydaniem Małej Czarnej i Małej Białej (Xiaobei yu Xiaobai《小黑与小白》).

Drugi model to współpraca w obrębie założenia przedsiębiorstwa wydawniczego. Przykładem może być kooperacja pomiędzy Wydawnictwem XXI Wieku a międzynarodową oficyną Macmillan Publishers, która doprowadziła do powstania 
w 2011 r. pekińskiego Przedsiębiorstwa Kulturowego XXI Wieku Macmillan. Wydawnictwo to opublikowało m.in. serię książek Źródto młodości (Bulaoquan - 不老泉). Jest to bardzo istotna forma współpracy pomiędzy podmiotami wydawniczymi.

Trzeci model polega na ustanowieniu strategicznych powiązań pomiędzy współpracującymi. Jako przykład można tu podać strategiczne relacje nawiązane przez Wydawnictwo XXI Wieku z niemieckim Instytutem Badań Kultury Młodzieżowej oraz braterskie powiązania z niemieckim wydawnictwem Tillman. Chińska Młodzieżowo-Dziecięca Spółdzielnia Informacyjno-Wydawnicza zatrudniła jako swojego strategicznego doradcę Patricię Aldanę, przewodniczącą Komitetu Nagrody im. Hansa Christiana Andersena, przyznawanej przez Międzynarodową Izbę ds. Książek dla Młodych.

Czwartą formą są organizowane w Chinach targi książek o randze międzynarodowej i ustanowienie chińskich międzynarodowych nagród w dziedzinie literatury dla dzieci i młodzieży. W 2013 r. chińskie miasto Szanghaj ustanowiło i zorganizowało pierwsze Chińskie Międzynarodowe Targi Książki dla Dzieci w Szanghaju (CCBF), które odbiły się głośnym echem w Azji, a nawet na całym świecie. W 2014 r. Chińskie Międzynarodowe Targi Książki dla Dzieci podniosły rangę chińskiej Nagrody w dziedzinie literatury dziecięcej im. Chen Bochui, tworząc tym samym Międzynarodową Nagrodę w dziedzinie literatury dziecięcej im. Chen Bochui. Od tego czasu jest ona przyznawana nie tylko wybitnym chińskim twórcom literatury dla dzieci i młodzieży, ale także pisarzom zagranicznym.

Piątą formą internacjinalizacji jest wkroczenie na arenę międzynarodową i stworzenie ,jednego pasa i jednej drogi” (yidaiyilu 一带一路) w formie platformy wydawniczej literatury dziecięco-młodzieżowej. Dnia 27 sierpnia 2015 r. Wydawnictwo Młodzieżowo-Dziecięce w Zhejiang przejęło i wchłonęło australijskie wydawnictwo New Frontier Publishing, co było pierwszym przypadkiem zakupu zagranicznego wydawnictwa specjalizującego się w książkach dla dzieci i młodzieży przez wydawnictwo chińskie. Natomiast Wydawnictwo Jieli 28 sierpnia 2015 r. otworzyło oddział w Egipcie, który był pierwszą specjalizującą się w literaturze dziecięco-młodzieżowej zagraniczną placówką chińskiego wydawnictwa. Wydawnictwo Młodzieżowo-Dziecięce w Anhui i libańskie Digital Future 3 września 2015 r. otworzyły w stolicy Libanu, Bejrucie, spółkę joint-venture. Był to pierwszy krok w stronę międzynarodowego sojuszu jedwabnego szlaku literatury dziecięcej (silu tongshu guoji hequo lianmeng 丝路童书国际合作联盟).

Wiek XXI to zupełnie nowa era chińskiego czytelnictwa dziecięcego. Nadeszła wiosna dla całej literatury. Jak czytamy w raporcie z wyników ogólnonarodowej ankiety czytelniczej 2018, w badanym okresie książki czytało aż 80,4\% nieletnich Chińczyków w wieku 0-17 lat. Średnio na jedną osobę przypadało 8,91 książki, podczas gdy w początkowym okresie istnienia Chińskiej Republiki Ludowej jedna książka przypadała na 17 dzieci. 
Od proklamowania Chińskiej Republiki Ludowej minęło już 70 lat. W tym czasie nastąpiły gigantyczne zmiany społeczno-ekonomiczne, które nie tylko diametralnie przeobraziły Chiny, ale również pokazały całemu światu potężną siłę leżąca na Wschodzie. Chińska branża wydawnicza literatury dla dzieci i młodzieży spełniła zadanie kontynuacji na początku XXI w. dwucyfrowego wzrostu odnotowanego w XX w., zapoczątkowując wielką erę chińskiej literatury dziecięcej.

Warto zwrócić uwage na ciekawe zjawisko, jakim jest popularność polskiej literatury dziecięcej w Chinach. Zapewne przyczynił się do tego fakt, że Polska była jednym z pierwszych krajów, które na początku października 1949 r. uznały nowe Chiny. Ułatwiło to znacznie nawiązanie kontaktów, a następnie owocną współpracę tłumaczy i wydawców. Wydaje się jednak, że w tym wszystkim było coś więcej. Istotne było to, że szybko powstała w Chinach grupa młodych aktywnych polonistów, znających język polski wystarczająco dobrze, by z powodzeniem tłumaczyć książki dla dzieci. Autorka niniejszego opracowania, jeszcze we wczesnych latach 80 . z wielkim zapałem, oprócz wykonywanej poważnej pracy zawodowej, pracowała nad tłumaczeniem książek opisujących przygody Koziołka Matołka. Powodzenie, jakim cieszyły się one wśród dzieci w Chinach, skłoniło ją do dalszej pracy nad tłumaczeniami innych polskich książek dla dzieci, a następnie do podjęcia kolejnego poważnego wyzwania, jakim było przystapienie do tłumaczenia dzieł polskiej literatury współczesnej takich wielkich autorów, jak mistrz reportażu Ryszard Kapuściński czy noblista Czesław Miłosz oraz wielu innych.

Zapewne nie bez znaczenia w zainteresowaniu literatura polską w Chinach są bolesne przeżycia obu narodów, szczególnie w ubiegłym wieku. Wykształciły one pewne podobieństwo w rozumieniu roli literatury, w tym literatury dla dzieci. Jest to literatura wesoła i beztroska, ale równocześnie ucząca młodego czytelnika tego, co wartościowe i dobre. Jest ona zdecydowanie inna niż ponure baśnie skandynawskie czy okropności niektórych bajek anglosaskich. Literatura dziecięca z Polski dobrze trafia w oczekiwania młodych odbiorców z nowych Chin, czego dowodem jest imponująca lista wydanych polskich książek dla dzieci w języku chińskim.

Ostatnimi laty polskie książki dla dzieci cieszą się dużym zainteresowaniem na rynkach całego świata, zdobywając przy tym liczne prestiżowe nagrody i wyróżnienia. Dzięki wydawnictwom chińskim polska literatura dziecięca znalazła się także na Międzynarodowych Targach Książki w Pekinie, gdzie zaprezentowano najważniejsze polskie utwory. Szacuje się, że chińskie wydawnictwa nabyły w ostatnich latach prawa do publikacji bardzo wielu pochodzących z Polski ilustrowanych książek dla dzieci, a corocznie ukazuje się ok. 10 takich pozycji w przekładzie na język chiński. Jako charakterystyczne cechy polskich książek obrazkowych dla dzieci wskazuje się pełen życia i humoru język utworów oraz ich obrazowość i żywiołowość. Na okraszonych pięknymi ilustracjami kartach można znaleźć liczne zabawy interaktywne, które przyciagają dzieci, ćwicząc ich zdolność skupienia uwagi. Książki te są bogate w treść oraz mnogość przybieranych przez nią form, wystawiając na próbę 
umiejętność obserwacji oraz wyciagania logicznych wniosków przez najmłodszych, wzbudzaja przy tym silne emocje. Polskie książki ilustrowane dla dzieci oczarowuja bogactwem stylów, zastosowanych technik czy poruszanej tematyki, przyczyniając się do rozwoju wyobraźni miłośników literatury w różnym wieku i wywierając bardzo duże wrażenie na chińskich wydawnictwach oraz czytelnikach.

Lista polskich książek dla dzieci, na które Chiny zakupiły licencje:

1. K. Bajerowicz, Drzewo

2. K. Bajerowicz, Mrónkowy blok rysunkowy

3. K. Bajerowicz, Żabawny blok rysunkowy

4. J. Bajtlik, Nić Ariadny - greckie labirynty

5. M. Bień-Königsman, M. Dek, jOlé!

6. Baobaby Studio, Wytwórnik ekologiczny

7. K. Boglar, B. Butenko, Klementyna lubi kolor czerwony

8. M. Brykczyński, A. Antoniewicz, Chodzৃi o to, çy wiesz co to? Zwierzeta

9. M. Brykczyński, K. Bajerowicz, Opowiem ci, mamo, co robia mrónki

10. M. Brykczyński, K. Bajerowicz, Opowiem ci, mamo, co robia żaby

11. M. Brykczyński, D. de Latour, Opowiem ci, mamo, co robia pajaki

12. M. Brykczyński, A. Nowicki, Opowiem ci, mamo, co robiq auta

13. S. Cichocki, A. i D. Mizielińscy, S.Z.T.U.K.A.

14. I. Chmielewska, Cztery zanykte miski

15. I. Chmielewska, Dwoje ludzi

16. I. Chmielewska, Ktopot

17. I. Chmielewska, Maum

18. I. Chmielewska, Moc ktopotón. Wytwórnik

19. I. Chmielewska, Niebieska laseczka, niebieska skryyneczka

20. I. Chmielewska, Oçy

21. I. Chmielewska, Pamietnik Blumki

22. I. Chmielewska, $W$ kieszonce

23. D. Czernik-Cichocka, Kominiary/Piekarz:

24. A. Czerwińska-Rydel, M. Ignerska, $W$ szystko gra

25. M. Dymek, Jadłonomia, Gingko Book

26. E. Dziubak (il.), Klopoty rodu Pošyczalskich

27. E. Dziubak (il.), Posiyczalscy ida w swiat

28. E. Dziubak (il.), Posyczalscy na wyspie

29. E. Dziubak (il.), Posycrzalscy pomszczeni

30. E. Dziubak (il.), Po:̇yczalscy w przestworzach

2 Według danych Instytutu Książki większość przywołanych książek już została przetłumaczona na język chiński i wydana, a ponadto cieszą się one dużą popularnością wśród dzieci chińskich. 
31. L. Fabisińska, A. Gwis, Grayby

32. Z. Fabjanowska-Micyk, J. Grochocka, Banzai

33. A. Głowińska, Kicia Kocia (seria 25 tytułów)

34. J. Gwis, E. Piotrowska, Jajo. Jajka w gnieździe i kosmosie, caylli kogel-mogel dla dociekliwych

35. M. Jamkowski, M. Szymanowicz, Wielcy naukowcy

36. M. Jamkowski, M. Szymanowski, M. Szymanowicz, Wielcy wynalazcy

37. R. Janowski, M. Szymanowicz, Wielcy muzycy

38. I. Kaluta, J. Ambrożewski, Man Zou. Chiny dla dociekliwych

39. P. Karski, $W$ góry!

40. P. Karski, $W$ morze!

41. G. Kasdepke, T. Kozłowski, W moim brzuchu mieszka jakieś zwierzqtko

42. D. Kassjanowicz, A. Dudek, Cześć, wilki!

43. E. Kołaczyńska, A. Wójcicki, O.G.R.Ó.D.

44. E. Kozyra-Pawlak, Ja Bobik

45. E. Kozyra-Pawlak, Liczypieski

46. E. Kozyra-Pawlak, Szopięta

47. A. Królak, Wytwórnik domowy

48. N. Kucharska, Jak to dziata? Zwierzeta

49. N. Kucharska, Legendy polskie dla dzieci w obrazkach

50. N. Kucharska, Mity greckie dla diieci w obrazkach

51. G. Lange, Świat jest driwny

52. D. de Latour, Blok rysunkowy pajaka Kleofasa

53. K. Lipka-Sztarbałło, Lazienkowe pytania?

54. P. Liput, Rok w przedszkolu

55. A. Ludwicka, Matematyczna pizza

56. K. Łaniewski, A. Wójcicki, Binek i Pulpet w królestwie chinskiego smoka

57. K. Laniewski, A. Wójcicki, Binek i Pulpet w swiatyni Majów

58. M. Matoso, Wytwórnik góra

59. I. Mikrut, M. Kurczewska, Co sie zdarzyto w piórniku

60. T. Minkiewicz, Mapa prayszłości

61. A. i D. Mizielińscy, Ale patent!

62. A. i D. Mizielińscy, Dawno temu w Mamoko

63. A. i D. Mizielińscy, D.O.M.E.K.

64. A. i D. Mizielińscy, Kosmos

65. A. i D. Mizielińscy, Kto kogo zjada

66. A. i D. Mizielińscy, Mam oko na liczby

67. A. i D. Mizielińscy, Mam oko na litery

68. A. i D. Mizielińscy, Mam oko na miasteczko

69. A. i D. Mizielińscy, Mamoko 3000

70. A. i D. Mizielińscy, Mapownik 
71. A. i D. Mizielińscy, Mapy

72. A. i D. Mizielińscy, Mapy de Lux edition

73. A. i D. Mizielińscy, Miastečko Mamko

74. A. i D. Mizielińscy, Pod ziemia, pod woda

75. A. i D. Mizielińscy, Tu jesteśmy

76. A. i D. Mizielińscy, Zjedz to sam

77. A. Nowicki, Samochodowy blok rysunkony

78. M. Oklejak, Cuda wianki

79. U. Palusińska, Brzuchem do góry

80. M. Rusinek, Chopinek

81. R. Skarżycki, Hej, Jedrek! Gdzie moja forsa?

82. R. Skarżycki, Hej, Jedrek! Przepraszam, csy tu boruja?

83. P. Socha, Pszcroty

84. P. Socha, W. Grajkowski, Dræewa

85. E. Solarz, A. i D. Mizielińscy, D.E.S.I.G.N.

86. A. Sowińska, Przelkroje: owoce i warsywa

87. Z. Stanecka, M. Oklejak, Basia (seria 35 tytułów)

88. K. Świeżak, K. Bogucka, M.O.D.A.

89. M. Utnik-Strugałła, A. Ladecka, Mamma Mia!

90. P. Wechterowicz, Mrówka uychodzi za maż

91. P. Wechterowicz, Rybka $i$ stońce

92. P. Wechterowicz, $W$ pogoni za syciem

93. W. Widłak, E. Wasiuczyńska, Pan Kulecžka

94. W. Widłak, E. Wasiuczyńska, Pan Kuleczka. Dom

95. W. Widłak, E. Wasiuczyńska, Pan Kulecžka. Radość

96. W. Widłak, E. Wasiuczyńska, Pan Kuleczka. Skrzydta

97. W. Widłak, E. Wasiuczyńska, Pan Kuleczka. Spotkanie

98. W. Widłak, E. Wasiuczyńska, Pan Kuleczka. Swiatto

99. J. Wyrzykowski, Żeloglutki na placu budowy

Lista polskich książek, na których wydanie na Tajwanie sprzedano licencje:

1. J. Bajtlik, Auto

2. A. Czerwińska, M. Ignerska, $W$ saystko gra

3. J. Korczak, Jak kochać dziecko

4. J. Korczak, Król Maciuś Pierwssy

5. M. Węgrzecka, I. Zabielska, Maszprawa cztowieku

Książki dla dzieci przetłumaczone przez Wu Lan:

1. K. Bajerowicz, Drzewo

2. K. Bajerowicz, M. Brykczyński, Opowiem ci, mamo, co robia mrónki

3. K. Bajerowicz, M. Brykczyński, Opowiem ci, mamo, co robiq żaby 
4. K. Bajerowicz, M. Brykczyński, Opowiem ci, mamo, skad sie bierze miód

5. M. Brykczyński, A. Nowicki, Opowiem ci, mamo, co robia auta

6. M. Brykczyński, A. Nowicki, Opowiem ci, mamo, co robiq samoloty

7. M. Brykczyński, A. Nowicki, Opowiem ci, mamo, co robiq statki

8. I. Chmielewska, Pamiętnik Blumki

9. D. Czerniak, Kominiarz Piekarz.

10. W. Grajkowski, il. P. Socha, Pszczoty

11. A. Gwis, E. Piotrowska, Jajo. Jajka w gnieździe i kosmosie, çyli kogel-mogel dla dociekliwych

12. J. Gwit, L. Fabisińska, Grayby

13. M. Jamkowski, M. Szymanowicz, Wielcy naukowcy

14. R. Janowski, M. Szymanowicz, Wielcy muzycy

15. E. Kozyra-Pawlak, Ja Bobik

16. E. Kozyra-Pawlak, Liczypieski

17. E. Kozyra-Pawlak, Szopięta

18. N. Kucharska, Opowiem ci, mamo, co robiq koty

19. D. de Latour, M. Brykczyński, Opowiem ci, mamo, co robiapajaki

20. D. de Latour, I. Mikrut, Opowiem ci, mamo, co robiq narzedzia

21. A. Mizielińska, D. Mizieliński, Kosmos

22. A. Mizielińska, D. Mizieliński, Kto kogo żjada

23. A. Mizielińska, D. Mizieliński, Pod ziemiq pod woda

24. M. Mycielska, Ale patent!

25. M. Oklejak, Cuda-niewidy

26. M. Rusinek, Chopinek

27. Z. Stanecka, M. Oklejak, Basia i bałagan

28. Z. Stanecka, M. Oklejak, Basia $i$ basen

29. Z. Stanecka, M. Oklejak, Basia i biblioteka

30. Z. Stanecka, M. Oklejak, Basia i biwak

31. Z. Stanecka, M. Oklejak, Basia i dentysta

32. Z. Stanecka, M. Oklejak, Basia i Driadkowie

33. Z. Stanecka, M. Oklejak, Basia i gotowanie

34. Z. Stanecka, M. Oklejak, Basia i Mama w pracy

35. Z. Stanecka, M. Oklejak, Basia i nowy braciszek

36. Z. Stanecka, M. Oklejak, Basia i opiekunka

37. Z. Stanecka, M. Oklejak, Basia i pieniadz.

38. Z. Stanecka, M. Oklejak, Basia i plac zabaw

39. Z. Stanecka, M. Oklejak, Basia i przedszkola

40. Z. Stanecka, M. Oklejak, Basia i remont

41. Z. Stanecka, M. Oklejak, Basia i stodycze

42. Z. Stanecka, M. Oklejak, Basia $i$ tablet

43. Z. Stanecka, M. Oklejak, Basia $i$ taniec 
44. Z. Stanecka, M. Oklejak, Basia i telefon

45. Z. Stanecka, M. Oklejak, Basia i telewizor

46. Z. Stanecka, M. Oklejak, Basia i urodziny w muгeum

47. Z. Stanecka, M. Oklejak, Basia i wolność

48. Z. Stanecka, M. Oklejak, Basia i myprawa do lasu

49. Z. Stanecka, M. Oklejak, Basia i zwierzaki

50. M. Szymanowicz, Krasnoludki. Fakty, mity, glupoty

51. P. Wechterowicz, Mrówka uy ychodzi za maż

52. P. Wechterowicz, Rybka i stońce

53. P. Wechterowicz, $W$ pogoni za sycciem

\section{SUMMARY}

\section{CHILDREN'S AND YOUTH LITERATURE IN NEW CHINA}

The author describes the difficult beginnings of publishing in new China, a country devastated in large part by the Japanese occupation and civil war. Publishing houses of all types were then scattered over a huge territory and very few. This was particularly the case for publishing children's and youth literature. Despite this difficult situation, as early as the end of 1950, the first specialized publishing house for children and youth audiences was established in Shanghai. The author shows the difficult further way of building a large publishing movement and institutions cooperating with it, which specialized in work for children and youth audiences. It indicates the role of the publishing movement in expanding the education of children and young people in China. It signals the collapse of an excellent business in the gloomy period of the cultural revolution, and then shows a gradual rebirth, and then, again, the dynamic development of the industry in the early 1980s in connection with the implementation of the "reform and opening up" policy. An important stage in this dynamic development was the formation of a new media group aimed at children and youth audiences in 2000 - the Chinese youth and children's information and publishing cooperative. This has led to the creation of similar media groups throughout China. Over 70 years of operation, new China has made tremendous progress in the field of children's and youth literature and publishing. Interestingly, this process, especially in the initial period, was carried out in cooperation with its counterpart in Poland. Many Polish books for young Chinese readers have appeared on the Chinese market and this phenomenon continues to be beneficial for both sides. 